EGYED-GERGELY JÚLIA ${ }^{1}$ - HORVÁTH ANNA²

\author{
VITÁNYI IVÁN (1925-2021) \\ „NEM ELÉG DÍJAT NEM KAPNI, ÚGY IS KELL ÉLNI, HOGY NE IS ADJANAK"3
}

EGY SZABADSÁGSZERETŐ EMBER ${ }^{4}$ ÉLETE ÉS MUNKÁSSÁGA ${ }^{5}$

https://doi.org/10.18030/socio.hu.2021.4.273

\title{
RENESZÁNSZ EMBER
}

A 97. életévében, 2021. szeptember 6-án elhunyt Vitányi Iván neve és alakja rengeteg ember számára lehet ismerős. Otthonosan mozgott egymással - látszólag - ellentétes értékeket, világnézeteket valló közösségekben, és egyfajta küldetéstudat hajtotta azon meggyőződésében, hogy a kulturált és építő párbeszéd lehetőségét a különböző hátterű és nézetű csoportok között minden körülmények között igyekezni kell megteremteni és fenntartani, ha komolyan vesszük és múveljük a demokráciát. Márpedig Vitányi Iván élethosszig tartó ténykedése kristálytiszta bizonyságtétele annak, hogy a demokrácia a legkomolyabb játék mind közül.

Vitányi Iván hihetetlen sokoldalú, igazi reneszánsz ember ${ }^{6}$ volt. Filozófiai, szociológiai és politikai gondolkodó, a társadalom működésének logikáját és a társadalom összetartó erőit örökösen megérteni vágyó, folyamatosan beszélgető és folyamatosan író kutató, akinek tudományos elméleteit és gyakorlati mindennapjait áthatotta a múvészet, elsősorban a zene és az irodalom. Ő maga a megtestesítője a zene elmére gyakorolt hatásának: annak, hogy a zenehallgatás és a hangszeren való játék az emberi agy gyakorlatilag minden területét aktivizálja, egymással összekapcsolja, ezzel pedig átlagon felüli gondolkodáshoz, kreativitáshoz és memóriához járul hozzá. Széles zenei és irodalmi múveltsége lépten-nyomon előbukkant, állandó segítőtársa volt. Akár baráti beszélgetés, akár munkahelyi értekezlet, akár egyetemi tanóra vagy konferencia volt az alkalom, ha fontosnak és odaillőnek tartotta - és ez gyakran így történt -, akkor szavalt, énekelt, vagy leült a sarokban lévő zongora mellé játszani ${ }^{7}$ a beszélgetés, az értekezlet, az óra vagy a konferenciaelőadás adott pontján, ez hozzátartozott

1 Társadalomtudományi Kutatóközpont Kutatási Dokumentációs Központ.

2 Társadalomtudományi Kutatóközpont Kutatási Dokumentációs Központ.

3 Vitányi Iván szerette idézni egy barátjának ezen mondását - soha, semelyik rendszerben nem kapott érdemi kitüntetést (Kossuthvagy Széchenyi-díjat), és ezt nem is bánta (Sükösd 2021).

4 A szabadságszerető ember politikai tízparancsolatának első pontja szerint a szabadságszerető ember „megköveteli magának és megadja másnak a minden embernek kijáró tiszteletet, de megkülönböztetett tiszteletet, sem magának semmi címet nem követel, másnak pedig úrvoltáért, sem vagyonáért, sem hatalmáért, sem befolyásáért, sem ruhájáért megkülönböztetett tiszteletet nem ad, csak tisztességéért, vagy érdeméért; senki emberfia elött meg nem alázkodik, alázatoskodó megszólítási és köszönési módokat szájára nem vesz" (Bibó 1930-as évek).

5 A tanulmány nagyrészt Vitányi Iván munkáin és a 20. Század Hangja Archívum és Kutatóműhely gyűjteményeiben található szakmatörténeti interjúkon alapul.

6 Iványi Gábor jellemezte így, Vitányi Iván 90. születésnapján tartott köszöntőjében.

7 Az általa hosszú évekig igazgatott Népművelési, majd az abból kivált Mưvelődéskutató Intézetben (vagy ahogy rövidíteni szokás: a MÜKI-ben) is volt egy pianínó „ilyen célra” (Tibori Timea személyes elbeszélése alapján). 
az összképhez. „És mindig azzal a céllal, hogy megrázza, felrázza a hallgatót. Hogy vándor, gondolkodj! [...] Gondolkodj, gondolkodj és aztán járd a magad útját." Hitt abban, hogy a zene és az irodalom (összességében a kultúra) az alapja mind egymás megértésének, mind a társadalom fejlődésének.

„Ebben Bartók és József Attila mutat utat: hogy a harmóniát kint megteremthessük, belül is meg kell teremtenünk. A bent és kint magában foglalja az egész népet, az egész társadalmat, s olyan kultúrát - akkori szóval-olyan szellemiséget jelent, amelyben mindenki egységes, még ha nem is egyforma" (Vitányi 1993:21).

Vitányi Iván múvelődésszociológusként és egyetemi oktatóként hatalmas életmúvet hagyott hátra: jóval száz feletti cikke, publikációja, könyve jelent meg. Témái a zeneszociológiától a szociáldemokrácia jövőképén át a politikai és önéletrajzi emlékezésekig terjednek. Jó dolga van annak, aki írni szeretne róla, van hozzá alapanyag bőven. Nehéz azonban összefoglalni, mi mindennel foglalkozott - az is lehet, hogy efféle világi formában lehetetlen. Ripp Zoltán szavaival élve, világos, hogy mennyire „grandiózus vállalkozás volna teljes képet adni e tartalmas élet és gazdag életmü minden lényeges vonatkozásáról" (2015:91).

A magát társadalommegfigyelőnek tartó Vitányi egész életében a tudományos kutatás, a kulturális szervezőmunka és a politikai szerepvállalás hármasában mozgott. Állandó érdeklődés, energia és nyitottság jellemezte. Alapvető és az életét végig kísérő céljának, a társadalom megismerésének és jobbításának elméleti megalapozásához fiatalon eljutott: hitte, hogy a közösségek összetartásához és fejlődéséhez a szocializmuson és a demokrácián keresztül vezet az út, mindennek alapja pedig a kultúra. A modern szociáldemokráciát tartotta a legjobb „választásnak”, mint írta „Ez tette a legtöbbet az emberiség haladásáért, a szabadság, egyenlőség, testvériség, igazságosság, szolidaritás és vele együtt a rend, jólét és biztonság érvényesüléséért. A szociáldemokrácia vívta ki, hogy a legfejlettebb társadalmakban legalább jogilag és morálisan kötelezö legyen mindenkire (a nőkre, szegényekre, elesettekre, a különböző népekre, nemzetekre, kultúrákra, világnézetekre) kiterjedő egyenlöség" (2000:12). A szovjet típusú államberendezkedésben csalódott, a szocializmus eszméjében azonban soha. Hamar baloldali gondolkodóvá vált, ami számára „nem pusztán teoretikus, hanem morális választás" (Ripp 2015:92) volt, elköteleződése mellett egy életen át kitartott.

„Bartóktól tanultam a népet, József Attilától a szocializmust” (Vitányi 2014:62).

Életét kettősség kísérte végig, amely kettősséget könnyedén tudta szintetizálni magában: a népiesség mellett a modernitás; a hagyomány mellett az újitás; a népdal, a népmúvészet és a szociális forradalom eszméje mellett a magaskultúra és a liberalizmus könnyedén fért meg, egészítette ki egymást gondolkodásában és világszemléletében.

„[...] a Lukács-iskolában én voltam az egyedüli néptáncos, és a néptáncmozgalomban az egyedüli lukácsista" (Vitányi 2007:15).

Mélyen vallotta, hogy nem a származás, hanem az életmód és a kultúra határozza meg az embert. Hitt annak fontosságában, hogy mindenkinek egyforma eséllyel kell hozzáférnie a társadalom, a gazdaság és a kultúra adta lehetőségekhez. Ugyanakkor úgy tartotta: „Nem csak azt kell szorgalmazni, hogy a kultúra minden fajtája, tehát legnagyobb értékei is hozzáférhetőek legyenek mindenki számára, de a társadalomnak arra is fel kell készíteni tagjait, hogy igényük legyen rá" (Vitányi 2000:37).

Hosszú élete alatt talán egyetlen ellensége volt, a fasizmus, barátja azonban annál több. Közösséget építeni, mindenkiben megtalálni az értéket, a környezetében lévő emberekre és barátokra igazán odafigyelni, 
a munkatársaknak szabadságot és felelősséget adni - ezek mind alapvető értékek voltak szemléletében. Tibori Timea, aki hosszú évekig munkatársa és barátja volt, a következőképpen fogalmaz a Vitányi Iván körül működő kutatócsoport(ok) kapcsán: „Nem szeretni kellett egymást, hanem odafigyelni a másikra.” Vitányinak „tipikus személyiségjegye volt, hogy elöhívta, hogy mi egy közösség vagyunk." Ezen felül "hihetetlen érzéke volt a tehetségekhez.” „Személyiségeket teremtett.” Szellemiségét sokan viszik és adják tovább.

\section{NAGYAPÁM NAGYAPJÁNAK APJA}

Vitányi Iván alapvető fontosságúnak tartotta gyökereit, önmagát - többek között - ennek révén határozta meg. Egyenes- és oldalági őseit - apja nyomdokain - hihetetlen akkurátus munkával kutatta és jegyezte fel. A tőlük kapottakat magával vitte egész életében. A történelem különböző pontjain szerepet játszó felmenőkre büszke volt, kereste családtagjai személyes „hozzájárulását” a világ alakulásához. Ugyancsak kereste családja múltjában az íráshoz való kapcsolódást, és számos ponton meg is találta: könyv, kiadott és kiadatlan versek, naplók, megjelent szerelmeslevelek. Vitányi egy ősénél sem felejtette el kiemelni ezeket önéletrajzi írásaiban. Mindezek sok helyen felbukkannak Vitányi múveiben, egyértelmúvé téve, milyen meghatározó igazodási pontok voltak számára. Nem véletlen így az sem, mennyire fontosnak érezte saját hozzájárulását országa sorsához, és mennyire fontos szerepet kapott az írás saját életében is. Könnyen, sokat, sok mindenről írt.

„Így lett az én nagyapám nagyapjának apja, Vitányi Gergely református pap Zsércen, az ő fia József pedig Megyaszón. [...] Az egyházközség tanulmányokban is megörökitette emlékét. Legidősebb fia, szintén József 1848 márciusában a márciusi ifjak között vitézkedett, erről szóló levele ma is a birtokomban van, s a világosi fegyverletételnél is. Ezt követöen hadifogságba került Olaszországba, amelyröl kiadatlan naplót örzök" (Vitányi 1996:50).

Vitányi Iván Debrecenben született 1925. július 3-án, középosztályi családba. Édesapja, Vitányi Iván (1889-1957) közjegyző, édesanyja, Szentpály Panna (1893-1954) háztartásbeli volt. Mind apai, mind anyai ágon nemesi származású, azonban itt is egyfajta kettőség volt jelen életében. Édesapja családja nem volt gazdag, Vitányi megfogalmazásában „csak abban a nem lényegtelen dologban különböztek a parasztoktól, hogy nem voltak jobbágyok" (2007:5). Édesanyja családja a nemesi középosztály másik rétegéhez tartozott, ők már módosabbak voltak. A két ágról a legkülönfélébb érdeklődéssel és ismertséggel rendelkező rokonok gazdagították a családot, ezáltal Iván gyermekkorát és családból hozott „örökségét”. Édesanyja rokona volt többek között Horthy Miklósnak, György Aladárnak, a színházi Böjthy-dinasztiának, közvetetten Vlad Dracul, közismertebb nevén Drakula grófnak, Ferenc Józsefnek (egy törvénytelen gyermeknemzés következtében) és mindemellett a fél történelmi Magyarországnak. A családot - többek között - a Kölcsey-családdal is több szál kötötte össze, egy alkalommal Vitányi egy parlamenti vitában ${ }^{10}$ személyes érintettség jogán, mint Kölcsey Ferenc rokona kért és kapott szót. Szentpály felmenői között volt Szentpály István, Bethlen Gábor levéltárosa és követe, akinek levelezése „Rejtelmes levelek” címmel jelent meg, Szentpály Ferenc, aki saját korában gunyoros verseiről volt ismert költő vagy Szentpály Janka is, aki romantikus regényeket írt, de fogságban lévő vőlegényével való levelezése is nyomtatásban jelent meg. Ősei között volt, aki a törökök ellen, volt, aki a Rákóczi szabadságharcban vagy az 1848-as eseményekben jeleskedett, de volt polgármester is, akiről utcát neveztek el Miskolcon, és volt Amerikába települt orvos is, aki a rák gyógyításának akkoriban meglehetősen ismeretlen és idegen metódusú kutatásával foglalkozott, és aki magánklinikáján, az épp előtte autóbalesetben megsérült

9 Tibori Timea személyes elbeszélése alapján.

10 Torgyán József 1996 márciusában mondott híres-hírhedt, Himnuszra is hivatkozó, az akkori kormányzópártokat támadó, „Kormánybúcsúztató" beszéde miatti vita. 
fiatal Henry Fordot is ápolta egy alkalommal a családi elbeszélés szerint. Ahogyan Ripp Zoltán találóan írta: „Mintha »fordított Adyként « rokona és ismerőse volna »mindenki« szerte e hazában" (2015:92).

Vitányi az otthonról hozottakról így fogalmazott: „Apám családjában a nyugalom és a megállapodottság volt a legföbb érték, anyáméban a mozgalmas, újat kereső szellem” (1996:55). Szüleitől magyarságtudatot és liberalizmust, az olvasás és a zene szeretetét, a tisztesség és a becsületesség fontosságát hozta magával.

„Sárospatakon kiváló zeneoktatás folyt, ami elsősorban Szabó Endre zenetanár érdeme volt. [...] Ő beszélt nekem elöször Bartókról. Lejátszotta néhány müvét hanglemezröl [...] Az élmény megváltoztatta életemet. Más nép jelent meg elöttem, mint amit eddig ismertem. A szenvedélyes küzdő, kemény, tragikus és mégis győzelmes néppel találkoztam, és megértettem, hogy ehhez a néphez kell tartozni, nem az úri osztályba, amelybe beleszülettem" (Vitányi 1996:62).

A széles értelemben vett családi háttéren, szakmai és baráti hálón túl Vitányi Iván gondolkodására legerősebben (többek között): Bartók Béla, ${ }^{11}$ József Attila, Ady Endre és Veres Péter, Kant, Hegel, Konfucius, Heidegger és Marx, Hajnal István és Erdei Ferenc, később Somogyi Miklós, Muharay Elemér, Karácsony Sándor, Kőrösi József, Lukács György és Nagy Imre hatottak. És a sort még sokáig lehetne folytatni.

\section{TALÁLKOZÁS A TÁRSADALOMMAL}

Vitányi Iván sok minden lehetett volna, élete válaszutai, vagy ahogyan ő fogalmaz, határhelyzetei (és döntései ezekben) határozták meg sorsát, vitték különböző területekre, de mindig ugyanabba az irányba. Ahogy maga írta: „Aki tizenéves koromban látott, könnyen elképzelhette leendő pályámat. Rengeteget olvastam, zenéltem, az iskolában szavaltam. Egyenes út vezetett tehát valamely egyetem történelem vagy irodalom szakára, esetleg a zeneakadémiára [...] Hogyan fordult meg mindez? Úgy, hogy találkoztam a társadalommal" (2007:7-8).

Életének szinte minden korszakában jelen volt a tudományos érdeklődés, a tudományos igényú gondolkodás, de egy részében a gyakorlatban is tudományos kutatásokkal foglalkozott. 1956-ban kezdett írni a Népszavába, majd a Magyar Nemzetbe és a Népszabadságba, 1958-ban pedig a Muzsika címú folyóirat szerkesztőségének lett állandó munkatársa. Élete igazi „társadalomtudományos fordulata” azonban 1964ben következett csak be, amikor a Valóság szerkesztőségébe hívták át, „amely ekkor a társadalomtudományi gondolkodás szinte egyedülálló nyilvános fóruma volt” (Szabari 2020:28). Ahogy maga is írta: „Ezzel belekerültem a tudományos és szellemi élet közepébe. Írók, szociológusok, közgazdászok, pszichológusok, történészek, múvészek, újságírók forgatagába" (2014:202).

A Valóság szerkesztőségében dolgozók többsége, Vitányit is beleértve, a reformkommunista tömbhöz tartozott, ami a hatalomhoz fűződő viszony tekintetében egyszerre jelentett együttmúködést és ellenzékiséget. A szerkesztőség és a pártközpont viszonyáról így írt Vitányi: „Időnként behivatták [a szerkesztőséget - a szerk.], hogy megbeszéljük a lap dolgait. Természetesen kifogásoltak ezt meg azt, mi ilyenkor igyekeztünk védekezni, olyan csendes hangon és olyan alapos érveléssel, amennyire lehetett. Az élni vágyás miatt jó arcot vágtunk mindenhez” (1996:109). A szerkesztőség tagjai valamennyien a „tưrhetőség határán” voltak (Vitányi 2014:237). A hatalommal - a szükséges mértékben - együttmúködtek, „játékszabályait” betartották, a rendszerkritikus kezdeményezéseket azonban saját eszközeikkel támogatták. Előbbi miatt egyes sorstársak, utóbbi miatt a hatalom fejezte ki néha nemtetszését. Vitányi hitt abban, hogy a külső forradalmaknak 1956-tal vége, utána a belső forradalom, a belső megújulás ideje jött el.

11 A szerzők, a cikk elolvasása után javasolják Vitányi Iván egyik kedvelt múvének, Bartók Béla III. zongoraversenyének a meghallgatását. 
A Muzsika szerkesztőségében még elsősorban a tánc (első könyve 1963-ban jelent meg A tánc címmel), a zene lélektana és a múvészetek szerepe az emberek mindennapjaiban voltak fő érdeklődési területei, de már itt is társadalmi szemlélettel, szociológiai és pszichológiai alapokkal és komoly kutatói hozzáállással közelített témái felé. A Valóságban a múvészetek világa mellett átevezett a társadalmi problémák leírása, és egyre inkább kutatása felé. Cikkeiben foglalkozott ideológiákkal, az emberi magatartást meghatározó alapkérdésekkel, a modern múvészet értelmezésével és védelmével, észleléssel, szemiotikával és színfiziológiával, a gondolkozás és a társadalmi élet szintjeivel, a beatmozgalommal, a zene és az ifjúság kapcsolatával, a szabadidő és a kultúra szociológiájával. Amint összefoglalóan írta: „Le kívántam írni a társadalom valódi problémáit, de egyben hitet akartam tenni amellett, hogy nemcsak új gazdasági mechanizmus kell, hanem új társadalmi mechanizmus, demokrácia, egyenlőség, gondolkodás, kultúra is" (2007:37).

A folyóiratnál a kutatást és a publikálást gyakran kötötte össze a modern (akkor támadott) múvészek és művészetek védelmével: „Nagyon beleillett a Valóság profiljába, hogy a müvészet (és a tudomány) új jelenségeit elemezzem, érvet adjak a dogmatikus támadások elleni védelmére” (Vitányi 2007:39). És: „A következő volt a filozófiánk: Mit kell tenni? Nem kell fejjel nekimenni a falnak, hanem segíteni kell minden elörevezető lépést. Ahogy Kovács András filmje fogalmazta meg: el kell mennünk a Falakig, de nem kell rajta betörni a fejünket, még szükség lehet rá. Vagy ahogy Karácsony Sándor Goethére hivatkozva mondta: »Egy háború elvesztése malör, egy parasztház leégése tragédia. "Jelmondatunknak tekintettük ezt” (Vitányi 2014:203). Jelmondatának és feladatának tekintette ezt, azaz a parasztházak (az ember és a közösségek, az egzisztenciák) saját eszközeivel való védelmét még hosszú évtizedeken keresztül, de anélkül, hogy átlépné a határt, amivel munkája ellehetetlenítését kockáztatná - onnantól ugyanis nem tudná folytatni a belső forradalmat, amivel, úgy érezte, többet segít, mint a nyílt szembeszállással (Vitányi 1996).

Vitányi itt, a Valóság munkatársaként fogalmazta meg híres elméletét: a minémúség-mennyiségminőség (quidditas-quantitas-qualitas) gondolkodási és egyben történelmi szinteket jelölő hármasságát. Rendszerében mind a gondolkodás, mind az emberi társadalom első, annak puszta milyenséget értelmezni tudó szintjét (minéműség), a második, a racionalitást alapul vevő, a dolgok elkülönítését is lehetővé tevő szintje (mennyiség), majd a harmadik, a legfejlettebb, az értéket és színvonalat is tartalmazó (minőség) szintje követi. Később ezt gondolta tovább a prométheuszi forradalmak sorát leíró elméletében is.

A folyóiratnál „könnyebb” témák is megmozgatták, folytatta például a zene és a társadalom kutatását. Empirikus kutatásainak egyik első eleme a hazai beatkultúra vizsgálata volt, amelyben az Illés, az Omega és a Metró együttesek tagjaival és rajongóival készített interjúkat, többek között Manchin Róberttel és másokkal együtt.

Foglalkozott a kultúra szociológiájával is, nevéhez köthető a kor egyik legnagyobb, országos reprezentatív mintán végzett szabadidő-kutatása, amelyben azt vizsgálták, ki milyen tevékenységeket végez, és azokhoz mely másik járul hozzá leggyakrabban. Az eredmények alapján négy nagy csoport rajzolódott ki: a passzív rekreativ, a rekreációs de otthonülö, a felhalmozó akkumulativ és egy, a kifejezetten a magaskultúrát is befogadó csoport. Amíg az első két csoportban a kultúra csak a periférián jelenik meg (és ők adták a lakosság többségét), a második kettőben már jelentős szerepet kap. Mint írta: „A kutatás képet adott a magyar társadalom helyzetéről, szerkezetéröl. Összefoglalva a magyar társadalom egyharmad-kétharmad osztatú. Felül van az egyharmad, ök élnek a 20. század közepének megfelelö anyagi és szellemi viszonyok között, ebben a körben vannak azok, akik az értékes kultúra iránt valamilyen szinten érdeklödnek. [...] Ezzel szemben a társadalom kétharmada nehéz körülmények közt él, és szabadidejét csak a házimunkával és a kocsma jellegü rekreációval tölti" (2007:46). 
Vitányi ezt a kutatást később többször is megismételte, egyharmadország elmélete pedig fontos alapköve lett társadalomtudományos munkásságának.

1972-ben új felkérést kapott és fogadott el, ekkor került a Népmúvelési Intézet ${ }^{12}$ kutatási részlegének élére, a híres Corvin tér 8-ba. Innentől - a Valóság szerkesztősége mellett - az intézetben folytatta társadalomtudományos munkáját, a társadalom és a kultúra, majd ezt kiterjesztve a közmúvelődés kutatását.

Először került egy nagylétszámú intézet vezetői székébe, ahol szabadszellemú, őszinte, nyitott, haladó és alkotó légkört igyekezett teremteni. Fiatal és szakértő csoportot gyűjtött maga köré a kutatásokhoz, de szoros baráti- és munkakapcsolatban volt az intézet többi osztályával, és az általa befogadott számos múvészeti alkotóközösséggel is. Hitt a különböző területek (akár a tudomány és a múvészet) együttmúködésében, abban, hogy az egymásra hatásokból csak jó születhet. Munkatársaitól elvárta az önálló gondolkodást, a legfrissebb szakirodalmak ismeretét és a közös munkát - amelyekhez minden tőle telhető támogatást megadott, és amelyekhez igazi, inspiráló és összetartó közösséget teremtett. Ahogy Tibori Timea fogalmazott: „Ő arra volt példa nekem, hogy csak akkor válhat valaki önállóvá, ha küzd a maga területén, alkot, próbálkozik, olykor sikeres, néha elbukik. Vitányi katalizátor volt. [...] Ha nem a terepen voltunk, akkor éjjel-nappal együtt voltunk, együtt ismertünk meg friss irodalmakat, amikről vitatkoztunk" (Csepeli 2015a:5-6).

Az intézet kutatói a korhoz képest nagyon szabad kezet kapva dolgozhattak, a kutatások részben önálló ötlet alapján, részben minisztériumi felkérésre készültek. Utóbbiakat a minisztérium többször valóban fel is használta, vagy legalább megfontolta, mindenesetre a kapott eredményeket komolyan vette. ${ }^{13}$ Bizonyos kutatásoknál (például egyes televíziós műsorok felmérésénél) fontos visszacsatolásnak számítottak a vizsgálati eredmények, más kutatásoknál azonban (például egyes világképelemzéseknél vagy Vitányi egyharmadország elméleténél) az Országos Tervhivatal nemtetszését fejezte ki, az eredményeket számonkérte vagy azokról tudomást sem akart venni (Vitányi 2007:62). A kutatóközösség időről időre összetűzésbe is került a hatalommal, részben a Vitányi által támogatott alkotóközösségek befogadása, részben a hatalomnak kevésbé tetsző kutatások miatt. Vitányinak nem egyszer kellett kiállni az intézet mellett, amit karakán módon magára is vállalt. Jól példázza ezt a következő anekdota is: „Valamilyen sugallatra Köpeczi Béla azt találta mondani Vitányi Ivánnak, hogy nincs elég paper, nem látszanak a kutatási eredmények. És másnap bejött Iván, behozott egy Vulkanfiber böröndöt, bepakoltatta velem a friss kiadványokat, majd hivott egy taxit, és azt mondta, most akkor átmegyünk a minisztériumba. Át is mentünk. Köpeczi szobájában ültek mások is, ez Ivánt nem érdekelte, és ilyen NÉKOSZ-os lendülettel, vagy, mint ha egy Jancsó-filmben látnám, kinyitotta az ajtót, és azt mondta, hogy „Kedves Bátyám, Kedves Köpeczi Béla! Behoztuk azokat a munkákat, amiről te azt állítod, hogy nincsenek! - és ezzel a lendülettel kiborította a börönd tartalmát az asztalra" (Csepeli 2015a:10-11).

Az intézet kutatási osztálya komoly elméleti és empirikus kutatásokat végzett. Vitányi, munkatársaival itt dolgozta ki világkép-koncepcióját, amelyhez a (zenei, irodalmi, filmes, színházi stb.) múvekben megjelenő világképet, és annak befogadóra gyakorolt hatását elemezte. „Alapja [...] a minémüség, a mennyiség és a minőség, ahol a mü lehet kiemelkedő esztétikai értékü vagy lehet népszerü, szórakoztató alkotás. A mü- és hatáselemzések együttesen mutatják meg, hogy befogadójuk miként reagál az alkotásokra, hogyan építi be a személyiségébe, vagy utasítja el" (Tibori 2020:179). A kutatócsoport az egyén reakcióinak vizsgálatára elemzési modelleket dolgozott ki, amelyeket később több területen is sikeresen alkalmaztak. Lendvai Ernő például a

12 A Népmúvelési Intézet a Múvelődési Minisztérium megbízásából népművelési témájú kutatások koordinálásával, felnőttneveléssel, népmúvelésképzési és honismereti tevékenység kialakításával, múvészeti képzéssel, alkotóházak, alkotótáborok indításával, amatőr múvészeti munkával és amatőr múvészeti mozgalmak támogatásával foglalkozott.

13 Tibori Timea személyes elbeszélése alapján. 
hangszerek és a mű világképének feltárásában, Józsa Péter és Jacques Leenhardt magyar-francia regényolvasatelemzésben, Kapitány Ágnes, Kapitány Gábor, Vörös Gizella és társaik pedig kedvelt lektürök és krimik világképértelmezésében (Tibori 2020).

Vitányi Sági Máriával fogott bele a korábban elemzett észlelés, szemiotika, pszichológia témáinak empirikus vizsgálatába, a kreativitás és generativitás kutatásba. A mű észlelésének és befogadásának vizsgálata mellett - Chomsky nyelvészeti koncepcióját a kultúrába emelve - kutatni kezdték az alkotás és befogadás kapcsolatát is. Alapfeltevésük szerint az ember azt tudja befogadni, aminek részleteit ő maga is meg tudja alkotni, a művet pedig aszerint fogadja be, mennyi ilyen eleme van. Fő kérdésük az volt, létezik-e az emberben zenei generatív képesség. Többlépcsős (különböző nyelvi bonyolultságú versekre zene rögtönzése, különböző bonyolultságú ismert összhangzattani kadenciákra dallam rögtönzése, különböző stílusú zenei múvek folytatása) és több társadalmi csoportra kiterjedő empirikus vizsgálatuk alapján arra jutottak, hogy „az egyszerü feladatokat a résztvevők túlnyomó többsége el tudta végezni. A zenei generativ képesség tehát él, de aluszik” (Vitányi 2007:58). Illetve Sági megfogalmazásában „...vizsgálataink azt bizonyították, hogy még a 'botfülü' is képes zenét létrehozni [...] hol a népdal jellegzetességeiböl épitkezve, hol az iskolában tanultak felhasználásával” (Tibori 2015:2). Eredményeikből a kultúra mindent (társadalmat és fejlődést) meghatározó fontossága rajzolódott ki: „Ha a zenében így van, feltehetöen így van minden másban. Elvileg meg lehetne alkotni minden ember, és így a társadalom kreativitásának térképét, azt, hogy kinek milyen ágazatban, milyen szinten müködik a kreativ és ennek következtében a befogadó képessége. Végső fokon-ezer áttételen keresztül - ez a térkép határozza meg a társadalom helyzetét, és lehetöségeit" (Vitányi 2007:58). Az elméletet tesztelni szerették volna más múvészeti ágakon is, a színekre vonatkozóan Vitányi S. Nagy Katalinnal és Deme Tamással kezdett bele a munkába, míg Feuer Mária és Strém Kálmán a zene befogadási struktúrájának kutatásával, Józsa Péter pedig a befogadás tipológiájának megalkotásával foglalkozott. Csepeli György később úgy értékelte Vitányi Iván generativitás elméletét, hogy „az egész magyar müvelődésszociológiának egy őrült nagy kitörési pontja van ebben a gondolatban [...] minden ember képes alkotásra. Iván ezt nem egyszerüen a nyelvi generativitás tekintetében ragadta meg, hanem átemelte a kultúrába, és az embert, mint kultúraalkotó lényt írta le és vizsgálta [...] az embert, mint kreativ lényt állította a szemünk elé" (Csepeli 2015b).

„Kirajzás” kutatásában, ugyanebben az időben, Hidy Péterrel a közmúvelődést, a népmúvelés helyzetét mérték fel. Egyszerű és pontos pillanatképet adó módszert választottak: adott pillanatban (egy kiválasztott szombati napon) jegyezték fel (a népművelési és a művelődésszervezői tanszékek hallgatóinak bevonásával), hogy az ország különböző művelődési intézményeiben mi zajlik éppen. Több száz múvelődési otthon napjába kaptak bepillantást (nyitva vannak-e, hányféle műsor, foglalkozás zajlik, hány látogató érkezik, milyen a dolgozói magatartás stb.). Az eredmények Vitányi egyharmadország elméletét támasztották alá: a művelődési házak harmadában voltak értékes rendezvények, valóságos civil társadalmi élet, sok vendég.

Korábbi szabadidő-kutatását több alkalommal is megismételte. A tíz évvel korábbi kutatás 1977-es ellenőrző felmérését Tibori Timeával, a hét ország részvételével zajló nemzetközi felmérést Lipp Mártával és Sági Máriával vezette, kérdőíves és mélyinterjús módszertannal (Göndör György és Füstös László komoly matematikai-statisztikai hozzájárulásával) és a család szerepének beemelésével: "az eredményt abban foglalhatjuk össze, hogy minden maradt a régiben. Nem kerültünk ki az egyharmadország helyzetéböl." Továbbá "a társadalom rétegződése öröklödik. A családban elsajátított kultúra keményen meghatározza a felnövekvő új nemzedék tagjainak helyét. Nagyon kevesen tudnak belöle kitörni, az iskola szerepe kisebb a remélhetönél" (Vitányi 2007:61). Ezt a jelenséget Vitányi familizmusnak nevezte, amely, mint megállapította, nálunk sokkal meghatározóbb, mint Amerikában vagy a nyugati országokban. 
„Ismét ott állt előttünk az egyharmadország. "Árnyéka" ott volt aztán minden későbbi munkámban, mondhatnám rögeszmémmé vált. Úgy éreztem, ebben tudom a legrövidebben, a legkeményebben és a legigazabban elmondani, hogy mi a jelen és a jövő Magyarország alapvető problémája - mert ha elöre akarunk menni, ebböl kell kitörni” (Vitányi 2007:62). A cél, hogy legalább kétharmadország legyünk „az ipartól a kultúráig és a müvelődési otthonig" (Vitányi 1985:18).

Mindezeket továbbvezetve, Wallerstein és Bibó nyomán jutott Vitányi a főútvonalas-centrális és a zsákutcás-perifériális fejlődés megkülönböztetéséhez. Elméletében előbbit a szerves, utóbbit a szervetlen fejlődési pálya jellemzi, előbbi a nyugati, utóbbi a mi utunk. Mint írta: „A szerves fejlődés mintegy alulról indul el és megy végbe, vagyis központi irányitás nélkül, a gazdaságban, a társadalmi életben és a kultúrában résztvevők saját elhatározásából. Ezzel szemben a szervetlen fejlődésben sokkal nagyobb a központi irányitás, és így mindenekelött az állam szerepe" (2000:61). Elméletét gyakorlati feladatokra váltva azt hangsúlyozta: alapvető cél kell, hogy legyen a szervetlen fejlődésnek és következményeinek felszámolásával a szerves útra való áttérés.

Ahogyan Tibori Timea összefoglalóan fogalmazott: „A Népmüvelési/Müvelődéskutató Intézetben folyó 1972-1992 közötti kutatásokat azért érdemes számba venni, mert ezek döntően Vitányi kultúra-felfogására alapozva kísérletezö, új módszertani apparátussal végzett, gyakran longitudinális jellegü munkák voltak." Ez a folyamat pedig „hozzájárult a korszerü fogalomalkotáshoz, a módszerek megújitásához, a kísérleti vizsgálatok elterjedéséhez" (2018:47).

A hetvenes évek közepétől kezdve a társadalomkutató Vitányi a nemzetközi színtéren is jelen volt. Részt vett a Nemzetközi Szociológiai Társaság munkájában, elnöke, majd tiszteletbeli elnöke volt a művelődésszociológiai munkacsoportnak. Több nemzetközi szervezet konferenciáján adott elő, illetve vállalt szerepet munkájában. Részt vett több UNESCO kutatásban és tagja volt a magyar bizottságnak. A szervezet keretében dolgozta ki többekkel együtt a közösségek helyzetének változását, sorsát, lehetőségeit középpontba állító, „Harambee” elnevezésű, együttmúködést sürgető projektjét. A vizsgálat végül nem valósult meg, az ötlet azonban szakmai körökben elismerést váltott ki. Az elnevezést a Luapula folyó hajómunkásaitól kölcsönözték, akik, hogy egyszerre rántsák a kötelet, amikor hajóikat a partról húzzák, éneklő hangon egyszerre kiáltják: Harambee! Vitányi a jól múködő közösség mibenlétét az összefogás ezen formájához társította (Vitányi 2007).

Vitányi elméleti gondolkodó volt, aki a gyakorlati problémákat egyből rendszerben tudta látni, illetve, aki egy empirikus kutatás eredményeit átfutva egyből meglátta az adatok mögötti rendezőelvet. „Ő először az elméletet látta. És szétnézett a terepen, ez esszenciális képessége, hogy kiválasztja a lényegi kérdéseket, és nem viszik el a jelenségek. Ez részben a müveltsége, de ez nyilván egy olyan fontos személyiségjegye, hogy azonnal meg tudta épiteni azt a struktúrát, amiben ő képes volt a problémát látni." Illetve "mint a szivacs, a dolgok lényegét átlátta. A mi tapasztalatainkba a legkülönbözőbb helyeken belenézett, jegyzetekbe, megfigyelési jegyzőkönyvekbe, egy-egy adatsort végignézett, és akkor ezt így félretolta, majd pedig megírta, hogy milyen a magyar társadalom állapota. És az a feneség történt, hogy alapvetöen neki volt igaza."14

Az intézetben vezetői, kutatói és kultúraszervezői feladatai mellett, a múvészeti mozgalmak új, modern hullámába tartozó, de tûrt kategóriába sorolt, segítségre szoruló csoportjainak támogatásában és védelmében is felelősséget érzett és aktiv szerepet vállalt. „Egyaránt szükség volt mindkettöre. Támogatásra, hogy helyiséget kapjanak, az önkormányzat segitse őket [...] És védelemre a meggyepesedett maradiság és ortodox hivatali baloldaliság támadásaitól” (Vitányi 2007:51). Az épületben előbb a korszak jelképei, a - Sebő Ferenc

14 Tibori Timea személyes elbeszélése alapján. 
és Halmos Béla neveivel fémjelzett - táncházmozgalom, fiatal képzőmúvészek vagy az akkor alakult színjátszó csoportok és irodalmi színpadok, amelyekben „a későbbi ellenzék bontogatta szárnyait” (Vitányi 2014:234) kaptak helyet, később, a nyolcvanas évektől „új mozgalmak jöttek, amelyek a közmüvelődés tereit a civil élet tereivé változtatták” (Vitányi 2014:240). Ahogy Vitányi fogalmazott: „Egyszer csak azt vettük észre, hogy már nemcsak a müvelödési mozgalmak, de a különféle politikai irányzatok otthonává is váltunk. Helyet adtunk összejöveteleiknek, vitáiknak, konferenciáiknak és aztán irodáiknak is" (2014:240). Teret kapott többek között például az 1956 történetét vizsgáló kutatócsoport (amely mind személyi, mind szakmai téren alapját adta a későbbi '56-os Intézetnek) és a Történelmi Igazságtétel Bizottság, Göncz Árpád, Püski Sándor és Makovecz Imre, az alakuló Magyar Demokrata Fórum, az Új Márciusi Front és a Szabad Kezdeményezések Hálózata, a népnemzeti jobboldal, a fiatal demokraták vagy a szociáldemokraták csoportjai.

Ha szükség volt rá, komoly védelmet is kaptak, mind az alakuló rendszerkritikus szerveződések, mind az intézet progresszívabb dolgozói. Többek között a Vitányi által igazgatott MÜKI-ben alakulhatott meg 1982-ben a Privát Fotó és Film Kutatócsoport. ${ }^{15}$ Ez különösen annak tükrében volt szokatlan, hogy általános közérdeklődésre nemigen tartott számot a privát, családi fotók - azok között is legfőképp az 1947-től a rendszer által „eltörlendő” emlékezetként kezelt nagypolgári, „burzsoá életmódot” megörökítő képek - gyűjtése és megőrzése. Ez az - állami intézmény keretei között végzett - archiválási munka értelmezhető a hivatalos történelmi narratívával szemben való kiállásként is. ${ }^{16} \mathrm{~A}$ Bán András és Forgács Péter ${ }^{17}$ együttműködésén alapuló, az amatőr fényképek és filmek szisztematikus gyűjtésére vállalkozó munka talán a ma sokak által ismert Fortepanhoz ${ }^{18}$ hasonlítható, ha úgy tetszik, annak elődje. Célja a személyes emlékezetek megőrzése, feldolgozása és bemutatása, ezekhez a megfelelő körülmények megteremtése, illetve a vizuális kultúra kutatásának és oktatásának támogatása volt. A PFFA kutatói a megőrzésen túl életútinterjúkat is készítettek az amatőrfilmek szerzőivel és hozzátartozóikkal, hogy feltárják a gazdag családi történetek kontextuális részleteit és megismerjék a készítók filmezéshez való viszonyát (Szemetová 2021).

$\mathrm{Az}$ intézeti védelem esetenként ennél is többet jelentett: Vitányi csapatának több tagja tartozott például azon kevesek közé, akik nem veszítették el állásukat, miután 1979-ben aláírták a Chartát. Ahogyan Havas Gábor mesélte: „Tehát volt ez a 79-es Charta aláirás. [...] És kvázi egy nyomás nehezedett a munkahelyi vezetökre, hogy akkor az elbeszélgetés nyomán valamiféle szankcionáló döntést is hozzanak meg. [...] tény az, hogy miközben az ebben az aláirási akcióban részt vetteknek egy nagyon jelentős részét elbocsátották vagy áthelyezték, tehát valamilyen komoly szankció érte, aközben bennünket, egyikünket se ért semmilyen érdemi szankció azon kivül, hogy a Vitányi a végén mondta, hogy ejnyebejnye" (Gárdos 2010:195). Ugyanez Vitányi szavaival a másik oldalról: „A Charta aláirásához tőlünk is többen csatlakoztak. Behivták a pártközpontba az aláirók intézeti vezetőit, és megkövetelték, hogy bocsássák el őket. [...] Én azt feleltem, hogy nincsen okom ráa az illetők kitünően végzik szakmai munkájukat. [...] Szigorú arccal vitatkoztak velem, de nem tágítottam. Az aláirók - nálunk - a helyükön maradtak" (2007:51).

De védelmébe vette az intézethez kötődő múvészeket és külső helyszíneket is. Ha tudta, az ellehetetlenítésükre irányuló próbálkozásokat is megállította: „Már a Népmúvelési Intézet igazgatója voltam,

15 Később alapítvány, PFFA.

16 Ahogy egy MÜKI-s hirdetésen olvashatjuk: „A családi fotók és filmek kiemelkedően nagy értéket képviselnek a nemzeti önismeret számára, a nemzeti hagyomány részét képezik [...] Nem szabad elveszni hagyni a régi idők értékes emlékeit, a fotókat, az albumokat, a filmszalagokat, és az ezekhez kapcsolódó leírásokat, történeteket!" (Szemetová 2021).

17 Több mint 30 filmje és installációja közül a legismertebb talán a PFFA-hoz köthető Privát Magyarország című díjnyertes sorozat, amely az 1930-as, '40-es és '50-es években - amatőrök által - készített felvételeken alapul.

18 A PFFA egyes gyűjteményeinek képei (Höfler Tibor gyűjtemény, Urbach gyűjtemény) a Fortepan oldalán is fellelhetőek. 
amikor egyszer kiküldtek hozzám néhány rendőrt, mert elterjedt, hogy a Sebőék Kassák Klubjában a zongora alatt szeretkeznek a fiatalok. Azt kérdeztem a rendöröktől: „Az urak jártak már a Kassák Klubban? « Azt felelték, nem. Közöltem velük, ott nincs is zongora. Pianino van, az alatt pedig nem lehet szeretkezni. Ezzel a probléma megoldódott, de nekem még számtalanszor közbe kellett lépnem" (Vitányi 1996:123-124).

Voltak azonban kudarcok is. Több színjátszó csoportot is rendszeresen zaklatott a hatalom, Vitányi több helyen is csalódottan írta, hogy Halász Pétert például nem tudta itthon tartani, el kellett hagynia az országot, "akkora maradi erők mozdultak meg ellene" (Vitányi 2007:51).

A közösségépítés, a különböző csoportok egymásmellettisége, az új kezdeményezések támogatása, a fennálló rendszer által tűrtek segítése - a parasztházak megmentése - mind Vitányi szellemiségéhez tartoztak. A magának kitǔzött feladatokat a később önállóvá tett Múvelődéskutató Intézet, ${ }^{19}$ majd az újraegyesített Országos Közművelődési Központ élén is ugyanúgy folytatta, ahogyan a Valóságból a P. Szűcs Julianna vezette Mozgó Világ szerkesztőségébe kerülve is korábbi témáit vitte magával.

Vitányi Ivánnak az intézetben töltött közel húsz éve meghatározó volt a saját, az intézet és az intézetben dolgozó vagy ahhoz kapcsolódó emberek életében is. Ahogyan Tibori Timea a személyes oldal felól közelítve fogalmazott: „Mindig biztatott. Mindenki számára látta a lehetőséget, hogy van útja. Más út, másképp, de van útja." 20 És ahogyan Földiák András a rendszer felől közelítve írta: „a hatvanas évek végén, a hetvenes évek elején megmozdult a világ. [...] Ezekhez a társadalmi folyamatokhoz illeszkedett a megújuló Népmüvelési Intézet, s nem túlzás azt állitani, hogy élére állt, és nem kis mértékben központjává is vált a haladásnak. Hogy ez megtörténhetett, s hogy az Intézet valóságos sziget volt, ahol a progressziv értelmiségiek szabadon dolgozhattak, s arra kaptak inspirációt, hogy az egyéni elképzeléseiket megvalósitsák, Vitányi Iván szelleméböl következett." Mint kiemelte: „A leghaladóbb, köztük országos hírnevü értelmiségiek kötődtek az Intézethez dolgozóként, külső megbizottként, vagy tanfolyami elöadóként" (1996:6).

1992-ben a Művelődési és Közoktatási Minisztérium rendelete értelmében az Országos Közmúvelődési Központ megszűnt, helyette megalakult a Magyar Művelődési Intézet, amely a korábbiaknál nagyobb hangsúlyt fektetett a hagyományőrzésre és a nemzeti értékekre. Vitányinak hamar mennie kellett az intézet éléről, többekkel együtt átkerült az Magyar Tudományos Akadémia Szociológia Intézetébe, majd később - a vezetéssel való egyet nem értések miatt - a Politikatudományi Intézetbe (Vitányi 2007:78). Tudományos munkáját egyre aktívabb politikai tevékenysége mellett továbbra is folytatta, kutatási ötleteket adott, egy-egy nagyobb kutatásban részt is vett.

Folytatta a kultúra társadalmi eloszlásának szerkezetét vizsgáló kutatásait, majd szakemberek sorával együttmúködve kétszer is megismételte korábbi $(1996,2000)$ empirikus szabadidős felmérését. Utóbbi vizsgálat fő következtetései szerint „A rendszerváltás után minden kulturális ágazatban megnőtt, kiszélesedett a kínálat, de csökkent a kereslet. Több könyvet adunk ki, de kevesebben olvasnak. Több koncertet tartanak, de csak egy szükebb közönség látogatja öket. - És így tovább" (Vitányi 2007:80). Egyfelől szomorúan állapította meg, hogy továbbra sem tudtunk kitörni az egyharmadország-állapotból, másfelől azonban új elem volt eredményeiben, hogy úgy látta, hazánkban az alkotó múvészet és tudomány az évezred elején fellendülő ágba került, újabb reformkorához érkezett. A szellemi reformmozgalmak 30 évenkénti szabályos ritmusában (1840es évek, kiegyezés, századelő, 1930-as évek, 1960-as évek) a 90-es évekre várhattuk volna a következő tetőzést,

19 A hatalom által tűrt kategóriába sorolt csoportok segítése miatt helyezték át Vitányi Ivánt átmenetileg a nagyobb Népművelési Intézetből az abból leválasztott kisebb Művelődéskutató Intézetbe.

20 Tibori Timea személyes elbeszélése alapján. 
ez azonban a rendszerváltás miatt a 21. század elejére tolódott, de akkor megérkezett. A kínálat tehát adott és magas színvonalú volt, Vitányi úgy gondolta, az már a kultúrpolitika feladata, hogy a társadalom tagjainak egyforma lehetőséget teremtsen, hogy aki szeretne, élni is tudjon vele.

Közösségkutatásában új utakon indult el, 200 darab értelmiségiek körében végzett mélyinterjú segítségével tervezte kidolgozni korábban felállított tipológiáját. A közösség Vitányi elméleteiben és személyes életében is központi helyen állt. Ahogyan már 1985-ben megfogalmazta: „A közösség nem rajtunk kívül van, nem puszta környezet, hanem mibennünk, minden ember legbelsejében. Csak megmozdulunk vagy megszólalunk, már a közösség mozdul és szólal meg bennünk" (1985:132). Elmélete szerint a hagyományos közösségek meggyengültek, kérdés, hogy talál-e az ember a kornak megfelelő új közösséget: a szociológiai irodalom kétféle közösségét, a hagyományos, elsőfokú közösséget (amelyben teljes személyiségünkkel veszünk részt, többnyire csak egyben vagy néhányban, például a család), és a modern társadalomban megjelenő nagyobb, másodfokú közösséget (amelyben személyiségünknek csak egy részével veszünk részt, egyszerre azonban sokban, például a munkahely vagy a település), kiegészíti-e a legújabb korban a megsokszorozódott kapcsolatok és a hálózatiság megjelenésével egy új típusú, harmadfokú közösség?

A politika és a társadalmi cselekvés irányából (amelyekben egyre aktívabban vett részt) kezdett foglalkozni a szociáldemokrácia elemzésével, a demokratikus szocializmus alapelveivel. Definíciójában ezek az alapelvek: ember embernek társa; a szocializmus nem állapot, hanem folyamat; a szocializmus a gazdasági és a társadalmi kulturális tényezők egyensúlya; egyformán fontos a rend és szabadság, illetve a szabadság, egyenlőség, testvériség eszméje; a szocializmus és a demokrácia csak együtt valósulhat meg.

Vitányi Iván több évtizedes, szerteágazó témájú, de mégis egy alapgondolatra (a társadalom mint közösség megértésére és fejlődési lehetőségeinek megtalálására) épülő kutatásain, tudományos munkáján saját elmélete húzódik végig. Ahogyan Csepeli György összefoglalóan fogalmazott: „...ha megnézzük Vitányi Ivánnak a témáit és megnézzük a módszereit és megnézzük a kutatási eredményeit, akkor ennek a háromnak egy fantasztikus együttjárását, a quidditas-nak, a qualitas-nak és a quantitas-nak az együttjárását tudjuk észrevételezni mindegyik müvében. Ez teszi szerintem abszolút mértékig originálissá és innovativvá" (2015b).

\section{EGY KÜSZÖBEMBER ÉLETÚTJA}

Vitányi Iván élete önmagában egy társadalomtörténeti „tananyag” az 1920-as évektől napjainkig. Társadalomtörténet középnézetből, egy küszöbember életútján és szemszögén keresztül, ami már csak azért is az egyik legjobb nézőpont, ha meg szeretnénk ismerni a történelmet a tankönyveken túlról, mert a küszöbember "ott áll a hatalom közelében, és ugyanakkor benne él a szélesebb társadalom mindennapi valóságában" (Vitányi 2014:7). Vitányi perspektívájából a legkülönfélébb társadalmi rétegek és csoportok is jól látszódtak, hiszen sokukban mozgott otthonosan. Olvasmányos, a társadalomba és a társadalmi életbe is bepillantást engedő önéletrajzi könyveit történelemórán is tanítani lehetne. Sokat érne.

„E világon ha ütsz tanyát,

hétszer szüljön meg az anyád!

Egyszer szüljön égő házban,

egyszer jeges áradásban,

egyszer bolondok házában,

egyszer hajló, szép búzában,

egyszer kongó kolostorban, 
egyszer disznók közt az ólban.

Fölsír a hat, de mire mégy?

A hetedik te magad légy!"

József Attila: A hetedik ${ }^{21}$

Bár valamivel később jött világra, mint Fejtő Ferenc, róla is elmondható, hogy átélt egy évszázadot. ${ }^{22}$ Fiatalkori éveit (számos település számos iskolája után) a sárospataki gimnázium, az ottani tanárok és szellemiség határozták meg. Tizenévesen már a pataki önképzőkör tagja majd diákelnöke volt, amellyel szavaltak és színjátszottak, vitákat rendeztek és falunapokon vettek részt, vasárnap a falvakat járva falumunkát végeztek. Meghatározó volt számára ez a közeg, az akkori népi mozgalom nagyjaival találkozott és kapott tôlük életre szóló útravalót: forradalmiságot, antifasizmust, a diktatúra elítélését, a gondolati és politikai szabadság értékeit.

Talán gyermek- és fiatalkori éveinek, az akkor átélteknek köszönhető, hogy kiválóan szót értett a más származású, más hátterű gondolkodókkal, tenni akarókkal - emberekkel. A Sárospatakon töltött évek hangulata (amelyeket megelőztek a szintén formatív kiskunhalasi évek és események) maradandó hatást gyakorolt rá világnézeti szempontból, ahogyan egyik önéletrajzi írásában fogalmazott: „Megrészegítő volt velük [az iskolatársakkal - a szerk.] a szabadság. Ültünk az iskolakert fái alatt. Az utcán német katonák meneteltek, olyan ismerősök jöttek el mellettünk, akik a zsidóknak már nem köszöntek, és mi Kantról vagy Marxról beszélgettünk, József Attila verseket vagy Karinthy novellákat olvastunk egymásnak" (2007:15). Gimnazistaként élte meg tehát először zsigeri értelemben az említett eszmék „összeférhetőségének” élményét: itt kezdődött a Vitányi által „kettőségként” aposztrofált folyamat, amely aztán átívelt egész életén.

1943-ban Pestre került, ahol történelem szakra és a Színmúvészeti Akadémiára kezdett járni - utóbbit unalmasnak találta, hamar otthagyta. Megismerkedett azonban a Muharay-együttessel, ahol megtalálta azt, amit keresett: a népmúvészet és a modernitás szimbiózisát, a bartóki-kodályi forradalom egyesítését a színházi avantgárddal. Az együttessel próbáltak, felléptek, és közben megvitatták a világ dolgait. Vitányi egy ilyen alkalommal alapította meg a pánarchiát (demokráciát és minden hatalmat mindenkinek) hirdető „Posz”-t: „Azt mondtam tehát a többieknek, hogy megalakult a világ leghaladóbb szervezete, a Pánarchista Okosok Szövetsége. [...] Ha pánarchista vagy, és okos, akkor eleve tag vagy, anélkül, hogy igazolványt kellene váltanod. Ha nem vagy okos, vagy nem vagy igazán pánarchista, akkor hiába kapnál róla papírt, mégsem lennél tagja a Posz-nak. Ezért ez a legdemokratikusabb szervezet a világon" (Vitányi 2014:71).

A vészterhes 20. század csapásaiból és tragédiáiból jócskán jutott életére, egészen fiatal korától kezdve: friss egyetemistaként részt vett az antifasiszta ellenállásban, tagja volt a Budapesten fegyveres felkelésre készülő Görgey-zászlóaljnak. A Kiss János altábornagy ${ }^{23}$ és Somogyi Miklós ${ }^{24}$ körül szerveződött ellenállók közé állt, futárszolgálatot teljesített, krétázott, röpcédulákat készített és terjesztett, igazolványokat hamisított, emberek bújtatásában segített, és közben a legkülönfélébb munkásmozgalmakkal kötött ismertséget. 1944 decemberében provokátor került az ellenállók közé, a 19 éves Vitányit és társait letartóztatta a Gestapo. Egyik önéletrajzi kötetében így írt az ekkor történtekről: „Iszonyatosan megkínoztak, botot törtek el a vállamon, puskatussal, gumibottal ütötték a fejemet, villanyoztak. Négy fogamat verték ki, maradandó sebek sorát őrzöm.

21 Vitányi Iván egyik „nagy verse”, ha beszédébe szőtte, hallgatóközönsége egy emberként, lélegzetvisszafojtva hallgatta - Tibori Timea elbeszélése alapján.

22 Fejtő Ferenc (1909-2008) életét foglalja össze az „Átéltem egy évszázadot” című interjúkötet.

23 A nyilas uralom megdöntését és a németek kiűzését célul kitűző földalatti szervezet (a Magyar Nemzeti Felkelés Felszabadító Bizottsága) katonai vezetője volt.

24 Az építőmunkások szakszervezetének elnöke, a Kommunista Párt egyik vezetője volt. 
A feljelentöm nagyon nagyokat mondhatott rólam, és ök azt gondolták, hogy egy ilyen sihederböl mindent kiverhetnek. Nekik nem sikerült, de nekem sikerült megöriznem magam, nem vallottam”25 (2007:19). Az első napokban a Gyorskocsi utcában, és a Margit körúti fegyházban, majd, az orosz hadsereg közeledése miatt Sopronkőhidán volt fogságban. Egyik rabtársa, Kaposi Zsigmond öngyilkosságba menekülésének, a véletlennek, a „csodának” és egy fiatal, titokban meggyőződéses antifasiszta vizsgálóbírónak, Keresztes Ferencnek köszönheti 1945 januári megmenekülését, életét (Vitányi 2014:105-106).

Hosszú, veszélyes és „kalandos” utazás után, 1945 májusában tért vissza Pestre, ahol, ahogy fogalmazott, hitt "az igéretben, hogy most nem a diktatúra, hanem a demokrácia útját követve jutunk el a szocialista társadalomhoz" (Vitányi 2007:21). Még ebben az évben belépett a Magyar Kommunista Pártba, ${ }^{26}$ majd 1948tól jogutódjának, a Magyar Dolgozók Pártjának lett tagja. Előbb a Muharay-együttesbe tért vissza, majd a Szabadszínjátszók Országos Szövetségének lett titkára, később a Népi Kollégiumok Országos Szövetségének (a NÉKOSZ-nak) volt kollégium-szervezője. Az együttesben ismerte meg későbbi feleségét, Haden Editet, és találkozott először Jancsó Miklóssal. Jancsó többször nyilatkozta, hogy később, a NÉKOSZ-os évek élményein alapuló Fényes szelek című filmjében róla mintázta egyik szereplőjét, a „vörös inges” alakját. Miután belső ellentétek és átalakítások miatt egymás után mindhárom helyről kizárták, rövid időt történelem-esztétikafilozófia hallgatóként a Pázmány Péter Tudományegyetemen töltött. Mestere, Lukács György ellehetetlenítése után azonban megint új utakat kellett keresnie. 1950-től segédelőadói állást kapott a Népmúvelési Minisztériumban, ahol hat évig a tánc, majd a zene területén dolgozott. 1953-ban belépett a Nagy Imre-féle reformcsoportba, majd a Petőfi Kör üléseinek volt az egyik legelső előadója és állandó résztvevője. Az 1956os forradalom alatt tagja lett a Magyar Értelmiség Forradalmi Bizottságának, ami miatt, a forradalom leverése után, „ellenforradalmi tevékenységére” hivatkozva eltávolították állásából. Ugyanabban a fegyházban hallgatták ki, ahol korábban a Gestapo „vendége” volt (Vitányi 2007:2931). A forradalom után elvesztve a reményt, hogy értelmiségi foglalkozást találjon, esztergályos tanfolyamra iratkozott be, amelyet el is végzett. Mint írta: „Amennyire ilyen kevés idő alatt lehetett, megtanultam az esztergálást. Élveztem, és letettem a vizsgát - a betanitott munkás szintjén. Nagyon büszke voltam rá. A szocialista romantika még hatott, terveztem, hogy belülről is megismerem a munkáséletet, szociográfiákat és regényeket írok belöle” (2007:32). Aztán „jöttek segédcsapatok" (Vitányi 2007:32), és elkezdődött társadalomtudósi élete. Az 1956-os forradalmat követően nem lépett be az MSZMP-be, a Népmúvelési Intézetbe történő kinevezésekor, 1972-ben lett csak párttag.

Nem meglepő talán, hogy felnőttkorára érdeklődése a nagy társadalmi és politikai kérdések és problémák irányába fordult, sokszor nem kerülve semminemú bajt és bosszúságot.

Vitányi Ivánt legtöbben talán politikai szerepvállalása révén ismerik. A magyar politikai közéletben végzett tevékenysége - ahogy a „színfalak” mögötti politikai szervezőtevékenysége is - történelmi ívű, bőven a rendszerváltást megelőzően megkezdett, annak folyamatában és azt követően is jócskán folytatott, párját ritkító jelenlét volt. Egyszerre volt előtérben lévő, forradalmasító vezető és háttérmunkás, annak megfelelően, hogy mire volt épp nagyobb szükség, hol érezte, hogy tevékenyebben tud hozzátenni a nagy egészhez.

A kulturális szféráról való elképesztő tudása és ismeretei alkalmassá tették volna döntéshozói pozícióra, azonban 1956-os múltja és demokratikus elvei miatt a Kádár-rendszerben nem lehetett sem múvelődési miniszter, sem miniszterhelyettes. Az 1980-as években ez felmerült, és Vitányi vállalta volna, az MSZMP keményvonalasai azonban megállították a kinevezési folyamatot, ezen felül akadémikussá léptetését is elkaszálták (Sükösd 2021).

25 Ahogy a kötetben is írta, később lélektani szempontból elemezte a fogságban, kínzások közepette eltöltött pillanatokat Széltenger cím írásában (Vitányi 2007:19).

26 1945-1956 között volt párttag. 
A hazai politika színterére „hivatalos” módon, pártpolitikusként a rendszerváltás közben lépett be, majd azon, élete végéig tevékenyen jelen is volt. Úgy érezte, miután mindent leírt, most eljött az ideje, hogy társadalmi szinten cselekedjen is. 1988-ban alapítója volt az Új Márciusi Frontnak, egy évvel később pedig a Magyar Szocialista Pártnak. Utóbbiban 1989 és 1994 között, majd 1998 és 2000 között az országos elnökségbe is beválasztották, míg 1990 és 1996 között az országos választmány elnöki tisztségét is ő töltötte be. A rendszerváltás utáni első szabad választásokon, 1990-ben pártja országos listájáról, 1994-ben és 1998-ban pedig Budapest 7. számú választókerületében, mint egyéni képviselő szerzett mandátumot. 1994 és 1998 között az országgyúlés kulturális és sajtóbizottságának elnöke, 1998 és 2000 között a párt frakcióvezető-helyettese volt. 2002-ben és 2006-ban pártja budapesti, 2010-ben pedig országos listájáról szerzett mandátumot. 2005 és 2006 között rövid ideig újra frakcióvezető-helyettes volt.

2010-ben csatlakozott a Demokratikus Koalíció platformhoz, amelynek egyik alelnökévé választották. A 2011-ben önálló párttá alakult Demokratikus Koalícióban az egyes számú párttagkönyvet kapta, a párt örökös tiszteletbeli elnöke lett.

\section{SZAKADATLAN HIT ÉS REMÉNYTELI KÜZDÉS - VITÁNYI IVÁN ÖRÖKSÉGE}

19 évesen, Sopronkőhidai fogsága idején cellaszomszédjától, Bajcsy-Zsilinszky Endrétől óriási feladatot kapott: ráhagyta a hazát. Vitányi a következőképpen idézi fel beszélgetésüket: „Volt részem a szolidaritás közösségéböl is. [...] Mindenki [a többi rab - a szerk.] idősebb volt nálam, és én mindenkinél sebesültebb, ezért két szóval is a legmélyebb összetartozást tudtuk kifejezni. A legemlékezetesebb Bajcsy-Zsilinszky Endrével való - mondhatom - barátságom. A szomszéd cellában volt, és a régi börtön-módon, a falon átkopogva, és membránnak használva szinte beszélgettünk. Egyik reggel - amikor az ajtón ki kellett tenni a küblit - azt kérdezte: Fiam, te kommunista vagy? Mondtam, hogy igen. A mú most már rátok marad. Nektek kell bevégezni. Másnap, december 24-én végezték ki. Utolsó akaratával rám hagyta a süteményt, amit a felesége küldött be. Én ezt majszoltam szentestén, a testem roncs volt, sok helyen fájt, de úgy éreztem, erös vagyok" (2007:20).

Az azóta eltelt több mint 75 évben rengeteg tőle telhetőt tett azért, amivel Bajcsy-Zsilinszky megbízta. És most itt vagyunk mi, egy következő generáció, és itt a feladat és a lehetőség, hogy tanuljunk abból, amit Vitányi hagyott ránk. Hát éljünk vele.

"S ha mindez volt, ahogy írva,

hét emberként szállj a sírba.

Egy, kit tejes kebel ringat,

egy, ki kemény mell után kap,

egy, ki elvet üres edényt,

egy, ki győzni segit szegényt,

egy, ki dolgozik bomolva,

egy, aki csak néz a Holdra:

Világ sírköve alatt mégy!

A hetedik te magad légy."

József Attila: A hetedik

Akár személyes, akár hivatalos beszámolók útján igyekszünk utánajárni, ki is volt valójában Vitányi Iván, sokféle úton sokféle megoldásra bukkanhatunk, ám a lényeg változatlan. Ahogy azt méltatói is kiemelték a 90. születésnapja alkalmából tartott ünnepségen a Petőfi Irodalmi Múzeum dísztermében, Vitányi 
beskatulyázhatatlan elme volt: „hiszen ki tudná megmondani, hogy népies vagy urbánus-e, netán olyan korábbi pártjából sokszor kiutált - liberális, akinek nem az individualizmus az eszményképe, hanem a közösség szabadsága az állammal szemben, aki nem privatizálni szeretne, hanem társadalmasítani, aki ezért nem jóléti államról, hanem jóléti társadalomról beszél, ahol a baloldal jövőjét tudja" (Friss 2015).

Politikai értékrendje viszonylag fiatalon kikristályosodott: a fasiszta rendszer természetét testközelből ismerhette meg, ez egy életre nyomot hagyott benne, ahogy sok minden más is a baloldal irányába terelte. Ugyanakkor éleslátásával, kritikus gondolkodásával és azzal, hogy mindig helyén volt a szíve, kiemelkedett a baloldaliak közül. Minden körülmények és megrázkódtatások közepette is tudta, merre van a helyes út, mi vezetheti a társadalmat a jó irányba, és nem ódzkodott attól, hogy ezt mások-legyenek azok vele egyetértők vagy más véleményen lévők - tudomására hozza. Tibori Timea szavaival élve: Vitányi Iván „nyilvánvaló volt”. ${ }^{27}$ Sokrétű tudásával a magyar társadalom régió- és országspecifikus jellegét illetően lényeges közéleti diskurzusokhoz járult hozzá érdemben, ha épp nem ő iniciálta azokat. Sok téren azonban ténylegesen kezdeményező szerepet vállalt, ahogy azt egy igazán, a szó legnemesebb értelmében vett szabadságszerető ember ${ }^{28}$ teszi. Személyes kapcsolataiban, akárcsak közéleti jelenlétében is a szabadság szeretete és mások tisztelete hatotta át jellemét: a megértés és elfogadás mellett erkölcsi szilárdság is jellemezte, ahogyan egyfajta szemérmesség is - nem szerette saját érdemeit taglalni, és dijak formájában kapott elismerésekre sem vágyott. ${ }^{29}$

Vitányi Iván nem csupán élte és átélte saját „történelmi sorsát”, egyidejúleg szinte kívülről is szemlélte azt. Talán történelemfókuszú, a történeti kontextust minden vizsgálódása és megnyilatkozása esetén szem előtt tartó szemléletének tudható be, hogy mindvégig reménnyel és tenni akarással teli, másoknak is reményt adó módon gondolkozott és beszélt a jelen és jövő lehetőségekkel teli mezeiről. Annak ellenére - vagy talán éppen azért - volt képes erre, mert sokunknál élesebben látta közös valóságunk mélyreható, szinte labirintusi börtön módjára fogvatartó nehézségeit. Saját szavaival élve: „Hogyan nevezzük ezt a helyzetet? Kevés azt mondani, hogy "nehézségek” vannak, de talán még nem tartunk ott, hogy válságról kelljen beszélnünk. Ezért gondolom, hogy a HOLTPONT rá a legmegfelelőbb kifejezés. A múlt század második felének óriási fejlődése után (amelyben gazdaságtörténészek szerint a gazdasági növekedés harminc év alatt nagyobb volt, mint az elözö ötszázban) a jóléti állam tartalékai kimerültek, elörevezető út nem látszik világosan; a válság még nem bontakozott ki, de kicsiny eseményekben fenyeget; a világ globalizálódott, de a belső konfliktusok mind élesebbek; háborús megoldások fenyegetnek, de a háború nem megoldás" (2004:39).

27 Tibori Timea személyes elbeszélése alapján.

28 A szabadságszerető ember politikai tízparancsolatának kilencedik pontja szerint a szabadságszerető ember „minden felismert közérdek ügyében kezdeményezőleg lép fel, minden közérdekü szövetkezésben vagy mozgalomban tehetsége szerint munkájával és adományával részt vesz s igyekszik azt győzelemre segiteni, tisztában lévén azzal, hogy a közügyek elhanyagoltsága vagy méltatlan emberek kezébe való kerülése egyedül a tisztességes emberek kezdeményezésének hiánya és közéleti bátortalansága miatt történik." (Bibó 1930-as évek).

29 Tibori Timea személyes elbeszélése alapján. 


\section{HIVATKOZÁSOK}

Bibó I. (1930-as évek) A szabadságszerető ember politikai tízparancsolata. Elérhető: http://tollelege.elte.hu/sites/default/files/ articles/szabadsagszereto_ember.pdf?fbclid=IwAR3QvIL6a--TXL3hxHIxKvZ4-Ms5umDbaDS29VI4nBsELBaEFeL7S-iwbSs [Letöltve: 2021-11-16].

Csepeli Gy. (2015a) Interjú Tibori Timeával. Kézirat. 409_08_01_43_01. 20. Század Hangja Archívum és Kutatómúhely, Szociológiatörténeti interjúgyújtemény.

Csepeli Gy. (2015b) Vitányi Iván életei. Csepeli György beszéde Vitányi Iván 90. születésnapi konferenciáján. Felvétel. Elérhető: https:// archive.org/download/Vitanyi90/00001.mp4 [Letöltve: 2021-11-16]

Földiák A. (1996) A Magyar Művelődési Intézet ötven évének öt korszakáról. SzíN, 1(2), 2-7.

Friss R. (2015) Ellenállástól ellenállásig. Elérhető: https://nepszava.hu/1062423_ellenallastol-ellenallasig [Letöltve: 2021-11-15].

Gárdos J. (2010) Interjú Havas Gáborral. Kézirat. 409_08_01_06_7. 20. Század Hangja Archívum és Kutatómúhely, Szociológiatörténeti interjúgyújtemény.

Iványi G. (2015) Iványi Gábor beszéde Vitányi Iván 90. születésnapi konferenciáján. Felvétel. Elérhető: https://archive.org/download/ Vitanyi90/00001.mp4 [Letöltve: 2021-11-16].

Ripp Z. (2015) A küszöbember. Mozgó Világ, 41(1), 91-96.

Sükösd M. (2021) Vitányi Iván és a mély felvilágosodás. Elérhető: https://merce.hu/2021/10/03/vitanyi-ivan-es-a-mely-felvilagosodas/ [Letöltve: 2021-11-15].

Szabari V. (2020) A magyar szociológia főbb korszakai (1900-2010). In Szabari V. (szerk.) (Disz)kontinuitások. A magyar szociológia 1960 és 2010 között. Budapest: ELTE Társadalomtudományi Kar, 20-39.

Szemetová L. (2021) Alternatív történelem a Privát Fotó és Film Alapítványon keresztül. Elérhető: https://osaarchivum.444. hu/2021/10/29/alternativ-tortenelem-a-privat-foto-es-film-alapitvanyon-keresztul [Letöltve: 2021-11-17].

Tibori T. (2015) Interjú Sági Máriával. Kézirat. 409_08_01_42_03. 20. Század Hangja Archívum és Kutatómúhely, Szociológiatörténeti interjúgyűjtemény.

Tibori T. (2018) A kultúra fogalmának változásai a 80-as évektől. Kultúra és Közösség, 9(1), 43-59.

Tibori T. (2020) Álomból valóság. Életmód - elmélet és gyakorlat. In Szabari V. (szerk.) (Disz)kontinuitások. A magyar szociológia 1960 és 2010 között. Budapest: ELTE Társadalomtudományi Kar, 165-197.

Vitányi I. (1985) Egyharmadország. Budapest: Magvető.

Vitányi I. (1993) Öt meg öt az tizenhárom (Az áprilisi front története). Budapest: Gondolat.

Vitányi I. (1996) Határhelyzetek. Budapest: Pallas Stúdió.

Vitányi I. (2000) Mérleg - Itt és most a szociáldemokráciáról. Budapest: Kossuth.

Vitányi I. (2004) Egyharmadország. Mozgó Világ, 30(1), 31-39.

Vitányi I. (2007) Önarckép - elvi keretben. Celldömölk: Pauz-Westermann.

Vitányi I. (2014) A küszöbember - Életem története Horthytól Orbánig. Budapest: Noran Libro.

\section{EGYÉB FORRÁSOK}

Vitányi Iván hivatalos oldala az országgyűlés honlapján. Elérhető: https://www.parlament.hu/kepviselo/elet/v047.htm [Letöltve: 202111-15].

Személyes beszélgetés két alkalommal Tibori Timeával (2021 októberében és novemberében). 